\title{
0-085＼cjkstart深頸部膿瘍の入院期間遷延に関連する要因
}

○福家智仁、山田弘之、福喜多晃平、金児真美佳、澤 允洋、上田航毅、小林大介

伊勢赤十字病院＼cjkstart頭頸部・耳鼻咽喉科

くはじめに>深頸部膿瘍は喉頭浮腫など気道狭窄の可能性があり、切開排膿や気管切開など早急な対応が求められる。さ らに敗血症や、縦隔へ膿瘍が波及した場合にはさらに致命的となり、加療期間が長期化することもある。今回、当科にて深 頸部膿瘍に対して頸部外切開を要した手術症例の入院期間について検討した。

<対象 > 2012年 1 月から 2018 年 6 月までの 7 年 6 カ月の間に頸部外切開を要した深頸部膿瘍症例36例を対象とした。男性 21例、女性15例であり、平均年齢は67歳（17〜90歳）であった。

＜結果 $>25$ 例で気管切開を併施し、4 例で膿瘍残存や増悪のために再手術されていた。手術後退院までに要した期間は平 均34.4日（最短 3 日〜最長101日）であった。

く考察＞当科では頸部外切開でのドレナージを行った症例では、抗菌薬投与と共に、ヨードホルムガーゼの挿入、交換に よる処置を基本としている。軽症な症例に対して、気管切開を要した例や、縦隔進展例、術後誤舆のリスクが高く経口摂取 に時間を要した例では、入院期間が遷延する傾向があった。

\section{0-086 頸部リンパ節結核の検討}

○伊藤文展 ${ }^{122)}$ 、石川直明 ${ }^{1)}$ 、橋本陽介 ${ }^{11}$ 、遠藤理奈子 ${ }^{11}$ 、和佐野浩一郎1)、南 修司郎 ${ }^{12}$ 国立病院機構東京医療センター 耳鼻咽喉科 ${ }^{12}$ 、慶應義塾大学 医学部 耳鼻咽喉科 ${ }^{2}$

日本は依然結核の中蔓延国であり、耳鼻咽喉科医として結核は頸部リンパ節腫脹の鑑別すべき重要な疾患の一つである。 今回2018年 1 月から11月までの間に当科で頸部リンパ節結核と診断した 5 例について、診断までの経過や診断方法について 検討を行った。男性 2 例・女性 3 例、年齢は23歳〜88歳（中央值72歳）、主訴は全例頸部リンパ節腫脹であった。結核の既 往があった症例は 2 例、排菌のあった症例はなかった。初診科は耳鼻咽喉科 1 例・他科 4 例であり、他科から依頼された時 点で結核を疑われている症例はなかった。当科受診時から診断までに要した日数は13日〜128日（平均值68日）で、確定診 断に至った検体採取方法は、リンパ節穿刺 1 例・外切開による生検 4 例であった。臨床経過や画像所見は症例によりさまざ まである一方、全例でT-SPOT は陽性であった。T-SPOT は結核を見逃さないためにも有用なスクリーニング検査になり 得ることが示唆された。

\section{0-087ＩgG4 関連硬化性顎下腺炎（IgG4 SSS）における血清 IgG4 值（sIgG4）の経年的変化}

$\bigcirc$ 今野昭義 ${ }^{1}$ 、植木雄司 ${ }^{11}$ 、間多祐輔 ${ }^{1)}$ 、川瀬勝隆 ${ }^{12}$ 、牛来茂樹 ${ }^{122}$

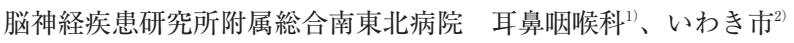

目的： $\mathrm{IgG}_{4} \mathrm{SSS}$ 15例を自然経過をみたA群 6 例（初診時平均 $\operatorname{sIgG}_{4} 271.2 \mathrm{mg} / \mathrm{dL}$ ）、両側顎下腺切除 B 群 5 例（平均 $\operatorname{sIgG}_{4}$ $544.8 \mathrm{mg}$ )、一側顎下腺切除 C 群 4 例（平均 $\mathrm{sIgG}_{4} 283.5 \mathrm{mg}$ ）に分け、さらにD群、非 $\operatorname{IgG}_{4} \mathrm{SSS}_{16}$ 例を含め、5〜12年間の $\mathrm{sIgG}_{4}$ の経年的変化と 2 次的な全身病変合併頻度を検討した。C 群 1 例、D 群 2 例を除き副腎皮質ホルモン処方はない。

結果： 5 年の経過で $\operatorname{sgG} G_{4}$ はA 群では 2 例を除き、またB 群では全例で低下し、B群の 2 例は 5 年、10年後に正常化し

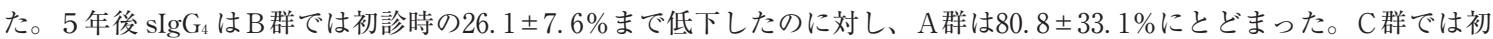
診時 $\operatorname{sIgG}_{4}$ 136 156mg の軽症 2 例が術後 $2 \sim 3$ 年で正常化したが、1 例で前立腺炎の合併による $\operatorname{sIgG}_{4}$ の急上昇を認めた。 またD群 2 例で二次的な $\mathrm{sIgG}_{4}$ 上昇と全身病変（後腹膜線維症による尿管狭窄と全身皮膚病変）合併を認めた。

\section{0-088 IgG4 関連疾患における顎下腺の線維化メカニズムの解析}

矢島諒人、垣内晃人、大和田 築、亀倉隆太、高野賢一 札幌医科大学 医学部 耳鼻咽喉科

今回われわれは IgG4-RD の特徴である高度線維化のメカニズムについて、顎下腺領域に着目し検討を行った。

IgG4-RD 患者の顎下腺組織より分離培養した線維芽細胞について遺伝子の網羅的発現解析を行ったところ、IL-6、IL18、TSLP、MMP1 で正常対照群に比して有意に発現の増加が認められた。これらについて免疫組織学的検討を行うと、い ずれも IgG4-RD 群の線維芽細胞に陽性像が認められた。

ここで IL-6 に着目したところ、IgG4-RD の線維芽細胞の IL-6 産生能は対照群より著しく充進しており、これは IL-1 $\beta$ 、 $\mathrm{TNF} \alpha 、 \mathrm{TGF}-\beta$ の処置により克進した。

さらに、ヒト肺線維芽細胞の増殖において IL-6 と共に重要な役割を担う WISP1 も IgG4-RD の培養線維芽細胞において 発現の増加がみられた。

また、培養線維芽細胞を IL-6、WISP1 それぞれで処置し、細胞周期を観察したところ、IgG4-RD、対照群いずれも G2/ $\mathrm{M}$ 期の増加が認められた。

以上の結果から IgG4-RD における高度の線維化は、炎症性サイトカインにより誘導された線維芽細胞産生の IL-6/ WISP1 を介した線維芽細胞の増殖によるものと考えられた。 


\section{0-089＼cjkstart放射線治療を行った頭頸部領域発症の木村氏病の 6 例}

○馬場洋徳、岩井玄樹、池田香織、高橋奈央、山崎恵介、松山 洋、堀井 新 新潟大学 医学部 耳鼻咽喉科頭頸部外科学教室

木村氏病の治療上の問題点として、手術による完全摘出が困難な例が多いこと、薬物療法ではステロイドの長期連用によ る副作用や休薬後の再発などが挙げられる。今回手術や薬物治療後に再発した木村氏病に対する放射線治療の効果と有害事 象を検証した。症例は2011年 9 月から2018年 8 月の間に放射線治療を行った再発木村氏病 6 例、全例男性、治療開始時の中 央值年齢は 34.5 歳であった。片側 5 例、両側 1 例、大きさは全例 $8 \mathrm{~cm}$ 以上であった。放射線治療は全例 $30.6 \mathrm{~Gy} / 17$ 分割で 行った。全例で病変の縮小を認め、3 例で消失した。治療後好酸球数は全例で低下し、IgEも低下したが正常化には至らな かった。急性期有害事象として Grade 1 の皮虐炎や口渴感、脱毛を認めるも後遺症なく全例で回復した。現在観察期間は 6 カ月〜87カ月であるが、全例で再増大を認めず、晚期障害も認めない。木村氏病に対する放射線治療は大きな急性期障害、 晚期障害もなく病変縮小が期待でき、再増大も認めにくい有効な治療の一つと考えられた。今後さらに長期効果について検 討して行く予定である。

\section{0-090木村病における T 細胞サブセットの検討}

○崎谷恵理、服部 藍、山村幸江、五島可奈子、野中 学

東京女子医科大学 耳鼻咽喉科

機能型 $\mathrm{T}$ 細胞には 4 種類のサブセットが存在する。慢性炎症・自己免疫疾患を引き起こす Th1 細胞（T helper type 1 cells)、アレルギー性疾患を引き起こす Th2 細胞（T helper type 2 cells）、免疫寛容を引き起こす制御性 T 細胞 (regulatory $\mathrm{T}$ cells)、炎症促進性サイトカインであるインターロイキン17を産生する Th17細胞（T helper type 17 cells）の 4 つであ る。またT細胞サブセットの分化誘導には T-box expressed in T cells (T-bet)、GATA3、retinoid-related orphan receptor $\gamma$ $\mathrm{t}(\mathrm{ROR} \gamma \mathrm{t})$ などの転写因子が関与している。われわれは、木村病の病態形成に重要な役割を果たしている因子を同定する ために次世代シークエンサー（Life Technologies 社のSOLiDTM4 システム）を用いて、木村病の病変局所に発現している 遺伝子を網羅的に解析し、今回はT細胞サブセットの分化誘導に必要な転写因子に注目した。さらに発現の高い転写因子に ついて免疫組織学的検討を行った。

\section{0-091＼cjkstart顎下部腫瘤から診断された全身性 IgG4 関連疾患の一例}

○清野由輩、藤川直也、波多野瑛太、山下 拓 北里大学 医学部耳鼻咽喉科・頭頸部外科

IgG4 関連疾患は血清 IgG4 高值と IgG4 陽性形質細胞浸潤と線維化を特徵とする、全身諸臟器の腫大や結節性病変を認め る疾患である。今回われわれは顎下腺生検の結果 IgG4 関連疾患と診断された症例を経験した。症例は71歳男性。左顎下部 の腫脹のため受診した。初診時、左顎下腺の腫脹が硬結として触れた。臨床検查所見では IgG 3, 268mg/dl、 IgG4 1, 350 $\mathrm{mg} / \mathrm{dl}$ と高值であった。画像検查所見は頸部造影 MRI 検查で左顎下部周辺から耳下腺下部にかけて不定形な T1、T2 共に 低信号域を認め、両側の眼瞼肥厚や涙腺腫大も認めた。造影体幹 CT 検査で縦隔、肺門リンパ節腫脹に加えて、後腹膜の右 腎内側、傍大動脈領域に軟部陰影を認めた。左顎下腺摘出を行い、病理組織学的にリンパ滤胞間に形質細胞の浸潤が見ら れ、CD138、IgG、IgG4 陽性細胞が分布しておう、IgG 陽性細胞中の IgG4 陽性細胞の割合は $50 \%$ 以上であった。以上の結 果より IgG4 関連疾患による一群の臨床症状と診断し、プレドニゾロン $30 \mathrm{mg} /$ 日で治療を開始した。投与後速やかに眼瞼腫 脹と顎下部腫脹が軽減し現在経過観察中である。

\section{0-092 当科における喠液腺腫瘍の臨床統計}

○宇佐美龍太 ${ }^{11}$ 、木村有貴 ${ }^{2}$ 、谷口雅信 ${ }^{2}$ 、渡邊昭仁 ${ }^{2)}$

自衛隊札幌病院 耳鼻咽喉科 ${ }^{11}$ 、恵佑会札棍病院 耳鼻咽喉科・頭頸部外科 ${ }^{2)}$

唾液腺腫瘍は頭頸部腫瘍の中でも決して頻度は高くないが、多彩な病理組織像を呈する。ゆえに術前骖断、術中の神経温 存の手技、術後治療の選択に苦虑することがある。1995年の当科開設から2018年11月までの過去23年間に手術を施行した唾 液腺腫瘍症例348例に対し、組織型、年齢と性別の頻度、術前診断、術後合併症、悪性腫瘍の治療成績について後方視的に 調查し検討した。発生部位別の症例数は耳下腺 269 例、顎下腺 71 例、舌下腺 2 例、小唾液腺 6 例であった。良／悪性の内訳 は耳下腺228/41例、顎下腺53/18例、舌下腺 $0 / 2$ 例、小唾液腺 4 / 2 例であった。組織型は手術当時の WHO 分類に準じた が、2017年の WHO 分類の適用が必要と判断した組織型に関しては病理学的再検討を行った。耳下腺良性腫瘍は発生亜部位 を浅葉、媣葉、下極に分類し、合併症の頻度につき検討した。その他、穿刺吸引細胞診の良悪性书よび組織型の診断感度、 悪性腫瘍の術後治療とその成績について諸家の報告と比較し考察する。 